\title{
Multidisciplinary team actions of a Brazilian Psychosocial Care Center for Alcohol and Drugs
}

\author{
Ações da equipe multiprofissional do Centro de Atenção Psicossocial Álcool e Drogas \\ Acciones del equipo multiprofesional del Centro de Atención Psicosocial Alcohol y Drogas
}

Liana Longo Teixeira Lopes'

ORCID: 0000-0002-2513-086X

Mara Regina Santos da Silva' ORCID: 0000-0002-7385-7609

Alessandro Marques dos Santos" ORCID: 0000-0002-0872-5925

Jacqueline Flores de Oliveira' ORCID: 0000-0002-0598-3881

'Universidade Federal do Rio Grande, Rio Grande, Rio Grande do Sul, Brazil.

"Universidade Católica de Pelotas, Pelotas, Rio Grande do Sul, Brazil.

How to cite this article:

Lopes LLT, Silva MRS, Santos AM, Oliveira JF. Multidisciplinary team actions of a Brazilian Psychosocial Care Center for Alcohol and Drugs. Rev Bras Enferm. 2019;72(6):1624-31. doi: http://dx.doi.org/10.1590/0034-7167-2018-0760

\section{Corresponding Author:}

Mara Regina Santos da Silva E-mail: marare@brturbo.com.br

Submission: 10-16-2018

Approval: 03-18-2019

\section{ABSTRACT}

Objective: to investigate the criteria used by health professionals to identify the phase of consumption of alcohol and drug users, and actions directed to their care. Method: a qualitative study developed with 14 professionals from a Brazilian Psychosocial Care Center for Alcohol and Drugs (Centro de Atenção Psicossocial Álcool e Drogas) based in the south of the country. Data were collected in June 2017 through semi-structured interviews and then submitted to thematic analysis. Results: the criteria used by the professionals were: periodicity of use; amount and type of drug used; repercussions of misuse; and place that the drug occupies in the person's life. The actions developed were orientation and referral to support groups, therapeutic workshops and individual care. Final considerations: the chronic nature of alcohol/drug use/dependence requires specific care in each phase, and objective criteria to identify and intervene in early phases, aiming at the prevention of chemical dependence.

Descriptors: Substance-Related Disorders; Patient Care Team; Mental health; Alcoholism; Nursing.

\section{RESUMO}

Objetivo: investigar os critérios utilizados pelos profissionais da saúde para identificar a fase do consumo em que se encontram os usuários de álcool e drogas, e as ações que realizam para o cuidado dos mesmos. Método: estudo qualitativo, desenvolvido com 14 profissionais de um Centro de Atenção Psicossocial Álcool e Drogas, localizado no sul do país. Os dados foram coletados em junho/2017, através de entrevistas semiestruturadas e submetidos à análise temática. Resultados: os critérios utilizados pelos profissionais foram: periodicidade do uso; quantidade e tipo de droga ingerida; repercussões do uso indevido; e lugar que a droga ocupa na vida da pessoa. As ações desenvolvidas foram orientação e encaminhamento para grupos de apoio, oficinas terapêuticas e atendimentos individuais. Considerações finais: a natureza crônica do uso/dependência de álcool e drogas requer cuidados específicos em cada fase, e critérios objetivos para identificar e intervir nas fases iniciais, visando à prevenção da dependência química.

Descritores: Transtornos Relacionados ao Uso de Substâncias; Equipe Multiprofissional; Saúde Mental; Alcoolismo; Enfermagem.

\section{RESUMEN}

Objetivo: investigar los criterios utilizados por los profesionales de la salud para identificar la fase del consumo en que se encuentran los usuarios de alcohol y drogas y las acciones que realizan para el cuidado de los mismos. Método: estudio cualitativo, desarrollado con 14 profesionales de un Centro de Atención Psicosocial Alcohol y Drogas, ubicado en el sur del país. Los datos fueron recolectados en junio/2017, a través de entrevistas semiestructuradas y sometidos al análisis temático. Resultados: los criterios utilizados por los profesionales fueron: periodicidad del uso; cantidad y tipo de droga ingerida; repercusiones del uso indebido; y lugar que la droga ocupa en la vida de la persona. Las acciones desarrolladas fueron orientación y encaminamiento para grupos de apoyo, talleres terapéuticos y atendimientos individuales. Consideraciones finales: la naturaleza crónica del uso/ dependencia de alcohol y drogas requiere cuidados específicos en cada fase, y criterios objetivos para identificar e intervenir en las fases iniciales, buscando la prevención de la dependencia química.

Descriptores: Trastornos Relacionados con Sustancias; Grupo de Atención al Paciente; Salud Mental; Alcoholismo; Enfermería. 


\section{INTRODUCTION}

Chemical dependence on alcohol and other drugs is a health problem that affects different dimensions of human life. The illness is chronic, gradual, extending over time, and may take many years to be diagnosed. This characteristic needs to be taken into account by the mental health multidisciplinary team as it is associated with the uniqueness of each person and the type of drug used.

Although it is not possible to establish the length of time that elapses until a person becomes dependent, the chronicity and graduality of this condition suggests that it goes through different phases, from the first contacts with alcohol and/or other drugs until dependence. In this study, supported by the classification used by the Brazilian Office of National Drug Control Policy (SENAD - Secretária Nacional de Políticas sobre Drogas) ${ }^{(1)}$, it is considered that the initial phase of the process is the one in which the person, called the occasional user, where the person has the first contacts with the drug, may use one or several substances, when available, in favorable environments and in specific or leisure situations. The use effects at this phase do not interfere in their family relationship, with their partners, friends, social life and academic or professional performance, because the drug's dosage is still small and its use is controlled ${ }^{(1)}$. At this phase, the occasional user is motivated, among other reasons, by curiosity, to join a group of friends, or by difficulties that he may be facing. Despite this, the fact of trying the drug does not mean that it will become chemical dependent; however, depending on the drug used, the chances are higher due to the degree of dependence.

In the second phase, the person is called an "usual user" due to the frequent use of the substance, although there are no affective, social or professional disruptions or loss of control over consumption ${ }^{(1)}$. However, the drug use has significant importance in the person's life and it can generate family and health problems. Moreover, at this phase, systematic and repetitive consumption can lead to dependence.

In the third phase, the person is identified as a dependent user, since this condition is already installed and the person cannot stop using the drug alone, even though the harmful consequences of abusive use are evident ${ }^{(1)}$. The Abstinence Syndrome and the development of drug tolerance are frequent, which leads to the need to increase the amount of the dose to have the same effects and previous symptoms. With this, the person tends to abandon their interests and commitments, in order to get the drug to feel the pleasures provided previously. Physical, emotional and social repercussions at this phase are more serious compared to previous phases ${ }^{(2)}$.

Although recommended by the Ministry of Health ${ }^{(3)}$, that professionals must act comprehensively, taking into account the individual needs of each person, according to the context in which they are inserted, it is known that some characteristics related to the user of drugs nor always considered. The type of drug used, the time of effect in the body and the potential of the substance to cause dependence are among these characteristics. Therefore, it is important to define care according to the phase in which the person is.

Thus, the type of drug used and the time it takes to cause dependence interfere with treatment, since each of them has its own characteristics and these indicate the best way to intervene. Stimulant drugs, such as cocaine and crack, have a faster effect when compared to alcohol. Thus, the faster the onset and the end of the drug effect, the greater the rate of dependence, which explains the rapidity of dependence when it comes to injecting or smoking drugs. Therefore, the chance of the person becoming dependent becomes much greater, when the time to the onset of the drug effect is fast and of short duration, as with crack ${ }^{(4)}$.

Personal characteristics also need to be taken into account in order for the treatment to be effective. Among these, there is genetic predisposition, environmental aspects (social, cultural, educational), behavioral aspects, such as curiosity, loss of a relative, low self-esteem, excessive responsibility, family conflicts, among others. In addition, some people take longer to reach dependence, while for others, this process develops more quickly ${ }^{(4)}$.

Therefore, based on the insidious and gradual characteristics of dependence on alcohol and other drugs, it is important that professionals adapt their actions to these characteristics.

\section{OBJECTIVE}

To investigate the criteria used by health professionals to identify the phase of consumption of alcohol and drug users, and actions directed to their care.

\section{METHOD}

\section{Ethical aspects}

The research project was approved by the Comitê de Ética em Pesquisa na Área da Saúde of the Universidade Federal do Rio Grande (CEPAS (freely translated as Research Ethics Committee in the Health Field) - UFRG). All the ethical precepts from Resolution 466/12 of the Brazilian Health Board (Conselho Nacional de Saúde), in force at the time of data collection, were respected. After exposing the study objectives and clarifications, all participants in the study signed the Free and Informed Consent Form.

\section{Type of study}

This is an exploratory study developed with a qualitative approach and focused on the performance of the multidisciplinary team in the different phases of the process of becoming dependent on alcohol and/or other drugs.

\section{Methodological procedures}

The study was developed with 14 multidisciplinary team professionals of the Brazilian Psychosocial Care Center for Alcohol and Drugs (Centro de Atenção Psicossocial Álcool e Drogas) located in the city of Rio Grande - Rio Grande do Sul State/Brazil. A semistructured interview was conducted based on guiding questions in the CAPS AD, in a reserved environment, according to the subjects' availability, without causing harm to their care routine. The first part of the tool addressed closed questions related to the participants' characterization as age, gender, race, training, specialization/area, training time, time spent at CAPS AD. The second part was composed of five open questions in order to answer the objectives of the study, according to experience in assisting users of alcohol and other drugs. This service choice is justified by the 
fact that it is composed of a multidisciplinary team and that acts specifically in the care for people who use alcohol and other drugs.

\section{Collection and organization of data}

The data were collected in June 2017, at a previously agreed time. In total, 14 interviews were carried out, lasting approximately 50 minutes, which were recorded in full, transcribed and organized. To guarantee the anonymity of the participants, the professionals were identified with a code using the letter P (Professional), followed by a number that indicates the interviews order.

\section{Data analysis}

The data were submitted to thematic analysis ${ }^{(5)}$, following three phases: the first consisted of the pre-analysis, in which the professional discourses were organized. Afterwards, the sense nuclei were searched, the data were grouped according to similarities and the clipping of the professionals' responses was extracted in relation to the central question. Finally, categories among themselves were identified, which allowed us to approximate the aspects that were interrelated and to identify the registration units by means of cuts directed by the themes, identifying the nuclei of meanings.

\section{RESULTS}

Data analysis made it possible to carry out a general characterization of the study participants and to group the results into two nuclei: (1) parameters used by professionals as defining the dependence process and (2) priority actions developed by the multidisciplinary team.

Table 1 - Study participants characterization: Rio Grande, Rio Grande do Sul, Brazil, 2017

\begin{tabular}{|c|c|c|c|c|c|c|}
\hline Code & Age & Gender & Training/Occupation & Training Time & $\begin{array}{l}\text { Postgraduate } \\
\text { Course }\end{array}$ & $\begin{array}{c}\text { Time Working } \\
\text { at CAPS AD }\end{array}$ \\
\hline P1 & 41 & M & Nurse & 16 anos & Specialization & 2 years \\
\hline P2 & 58 & $\mathrm{~F}$ & Social Worker & 13 years & Specialization & 2 years \\
\hline P3 & 36 & $\mathrm{~F}$ & Social Worker & 11 years & No & 3 years \\
\hline P4 & 44 & $M$ & Psychiatrist & 20 years & Specialization & 6 years \\
\hline P5 & 34 & $\mathrm{~F}$ & Psychologist & 10 years & Master & 4 years \\
\hline P6 & 34 & M & Art Therapist & 5 years & Master & 6 years \\
\hline P7 & 37 & $M$ & Social Educator & 18 years & No & 6 years \\
\hline P8 & 44 & M & Social Educator & 3 years & No & 3 years \\
\hline P9 & 44 & M & Nursing Technician & 10 years & No & 5 years \\
\hline P10 & 39 & $M$ & Psychologist & 17 years & Specialization & 2 years \\
\hline P11 & 38 & $\mathrm{~F}$ & Psychologist/Social Educator & 10 years & No & 3 years \\
\hline P12 & 56 & $\mathrm{~F}$ & Psychologist & 27 years & Specialization & 7 years \\
\hline P13 & 47 & $\mathrm{~F}$ & Psychologist & 21 years & Specialization & 6 years \\
\hline P14 & 38 & M & Art Therapist & 9 years & Specialization & 5 years \\
\hline
\end{tabular}

\section{1) Parameters used by professionals as defining the de- pendence process}

\section{Periodicity of drug use}

The periodicity criterion to identify the phase that the person is experiencing is measured by the frequency of the drug use, expressed in years, weeks or days. When it is more appropriate to express for years of intake, according to the participants, alcohol dependence is considered incontestable, because in these cases, it has already been established in a person's life for a long time. Nonetheless, weekly frequency is represented by the number of times in the week that the person uses a certain substance. In the occasional phase, in general, the user makes use of the drug at events such as birthdays, family parties, night parties. In the usual phase, the drug is used more frequently, on weekends or two to three times a week, starting to be part of the routine of the person. However, when the use is daily, the professional considers that the user is in the dependence phase.

[We observed] the prioritization of use such as if he says he is using on weekends. I ask him if during the week he also feels like it. The occasional, usually, is involved with some event, only 15 years or in anniversaries or [parties]. (P1)

Generally, the user who is looking for us is already an alcoholic for many years. He has been drinking for ten years, five years ago [...]. So, in these cases, dependence should not be contested. (P6)

The person says he uses every day, drinks in the afternoon, so he is a dependent. He works every day, but he is a dependent. He cannot get out of it every day. (P12)

\section{Amount of drugs used}

The drug dosage is another criterion used to establish the phase that the person is experiencing. In this case, there is no exact measure, as it depends on the type of substance consumed, and can be expressed in small, moderate or high doses. When it comes to dependence on alcohol, in addition to the amount consumed, it is considered the type of alcoholic beverage, such as distilled or fermented.

The dependence phase can be considered if the use is daily, even in small quantities. Tolerance for a particular substance is also a criterion that conditions the user to increase the dosage or substitution by other substances. The occasional user begins by ingesting a small amount of a substance and subsequently increases this amount gradually for better satisfaction, and may become dependent.

Other patients have the so-called "social use of small daily doses", supposedly small doses, but every day and that, somehow, can also have repercussions from apersonalor professional point of view and also characterize a dependence. (P4)

In dependence, she [drug user] cannot stop because at first she actually uses " $x$ ", then this " $x$ " increases, because that does not satisfy anymore [...] He comes here [at CAPS AD] in the morning and says he took five doses of alcohol. (P12)

\section{Type of drug used}

The type of drug consumed by the user is also a criterion used to establish the phase in which it is found. The dependence phase 
is defined according to the drug consumed, since crack and cocaine have this process accelerated when compared to marijuana. Alcohol, at the occasional and usual phase, is often referred to as a socially accepted drug with gradual effects. According to the participants, it is difficult to establish when the person changes from the usual use to the dependence, because this is a very thin border. Alcohol users seek treatment when dependence is already in place, that is, when the harm to their life becomes apparent. According to the participants, marijuana is associated with the occasional and usual user phase, used by adolescents undergoing experimentation or by adults as leisure, with no repercussions on personal and professional relationships. The marijuana user can usually maintain use for many years without compromising his daily life. Marijuana becomes a problem when combined with other drugs, such as crack and cocaine.

Of course, in another type of drug, such as crack cocaine, we already establish dependence, in a single view, in a single interview. But in general, it depends a lot on the drug because the power of dependence is different. (P1)

Marijuana does not take anyone out of the family; it does not stop studying, working because it uses marijuana. Alcohol and crack are the worst [drugs], in the sense of ravaging people's lives [...]. (P12)

\section{Repercussions caused because of the use}

This criterion is associated with the previous one, since each type of drug has a different repercussion in people's lives. In the occasional phase, the user, whether of marijuana, cocaine or alcohol, follows his routine normally, attends school, works and performs his daily activities without repercussion of the drug, since he has control. In the usual phase, the use of these substances is sporadic, but in high doses, it can alter the sleep, repercussions in the work with delays or in the university activities. In the dependence phase, including also crack, the losses are progressive in health, social, family, work, living conditions, material and affective losses. Family relations are greatly impaired because, at this phase, the user loses control of the situation, becomes aggressive and often steals family assets to obtain the drug. Physical aspects are visibly identified with a person's emaciation, lack of body cleanliness, sloppiness, depression, and demotivation. Critical users of dependence are compared to "zombies," because they roam the streets, denigrated, with no prospects of life, they are at "rock bottom". Women dependent on alcohol and other drugs are in poor conditions, depressed, abandoned by relatives and, as the case may be, their children are referred to the Guardianship Council, because they are not able to raise them.

[...] mainly, the crack-dependent he gets very sloppy, the appearance changes, it seems that the crack blackens the person [...] when he is in a very heavy use, gets very depressed, tearful, especially women. (P2)

We ask if the person can follow his or her routine. When you are young, you need to be in school, do the homework that the parents set up. If she eventually manages and smokes a marijuana cigarette, I do not consider myself a marijuana dependent [...]. (P14)

\section{Place that the drug occupies in the person's life}

The place that the drug occupies in the person's life is a criterion referred to by P1, P7, P12, to identify the phase that the individual is in. In the occasional user phase, the drug is used out of curiosity and it does not have much importance in the person's life. In the usual phase, the drug is used by the effects caused by the sensations, since it begins to occupy a place in the routine of the user, even if sporadically. In the dependence phase, the drug becomes part of the routine, becomes present and when not in use, the person is thinking about the next dose, misses it. Food begins to be replaced by the substance and is also consumed to give courage and courage to the person to face problems.

When we realize that a person can only perform important tasks, or face problems under drug use, dependence is already characterized. It is not just the use, the effect of the drug, but what it represents in the person's life. (P1)

It has to see the day to day of that person, as is the dynamics of her life [routine]. (P12)

\section{2) Priority actions developed by the multidisciplinary team}

Two actions were pointed out by the majority of the participants of this study, the orientation of the users and their relatives in relation to the process of becoming dependent and the referrals, mainly to activities developed in the CAPS AD itself.

\section{Orientation}

In the occasional user phase, the guidelines mentioned by the participants are related to the affective, financial, social and physiological damages that can be caused by the drug. P4, P10, $\mathrm{P} 12$ and $\mathrm{P} 13$ perform a reflection work with occasional users during psychotherapy on the perception of chemical dependence as a problem so that they perceive the commitment that the undue use of drugs can cause in their lives, both in the present particularly in the future, depending on the drug they use. In schools, when requested to CAPS AD, preventive work is carried out with adolescents. P6 performs this work through guidance on the effects of the drug, services available to users of alcohol and other drugs, and Mental Health as a whole.

Usual users are advised by professionals about the risks of becoming a chemical dependent because of the increased frequency of use. That is, he used the drug only on weekends and started using it during the week as it is important for the person to recognize this dissatisfaction in using the drug sporadically, in addition to the negative repercussions that can be caused by the undue and continuous use. With this, usual users are directed to reduce the consumption or to stop totally. According to the participants, change of habits must take place, in which users need to organize their routine in a way that their daily commitments and tasks do not refer to the use of the drug, as well as the social environment they attend, make improper use, either places that facilitate this use.

It is noticed through the lines that professionals guide the dependent users during support groups and individual service 
on the restructuring of social, personal, family and affective relationships that have been harmed by chemical dependence, in which the objective of the treatment consists in the social reintegration of the person dependent on alcohol and other drugs and not abstinence.

I think in the first [phase], in the occasional it is even more the prevention. On the question that can become a dependence. If the person is perceiving this, if he already sees some damage or that he can become dependent. (P5)

We ask, advocate or indicate that he changes his habits, change his routine so that he does not remember the use. (P1)

It is a total ransom of the person, of self-esteem, of being able to recognize yourself as something positive. Do not just look at what you've lost. Because depression hits the person. (P5)

The treatment is to do the proposed activities, interact with family, reorganize better your life, not only stop with the use [of the drug]. (P11)

\section{Referral}

Occasional users who eventually arrive at the CAPS AD are treated separately, so that they do not feel stimulated by the testimonials of users who use one or multiple drugs for a longer time. Adolescents who are in the beginning of the use, are sent to individual attention with psychologists, psychiatrist and, if necessary, to the therapeutic workshops of arts or music, according to their interest. Only those over 18 participate in support groups.

Usual users are referred for individual care with psychologists, support groups (multiple drugs) and therapeutic workshops, according to the abilities of each one. Family members who accompany the users to the service are referred to the family support group and, when requested, can talk individually with a staff member who is available. Family group is held once a week and only one relative per group can attend at a next meeting another family participates.

For the dependent user, a Unique Therapeutic Project (PTS Projeto Terapêutico Único) is elaborated by the psychologist, which is later discussed in the team meetings. This PTS is performed based on the assessment of each user's needs. From this evaluation, the user is referred to the services offered in CAPS AD itself. Services are provided with the multidisciplinary team, such as psychiatric consultation, psychotherapy, nursing consultation, support groups, individual and group therapeutic workshops.

Referral to support groups is a priority for the CAPS AD, since the proposal is for the social reintegration of these people. Multidrug support groups, alcoholics groups, women's groups and family support groups are offered. The groups are held weekly and given by one of the team professionals. In the therapeutic workshops, performed by art therapists, activities are performed, such as paintings, drawing, crafts and music, with artistic activities according to the aptitude and creativity of each user of the service. In support groups, themes related to the repercussions caused by substance abuse in the social, family, work, physical and psychological aspects are addressed. With women who use alcohol and other drugs, specific activities are also carried out, addressing, for example, the issue of being a woman and a dependent mother, as well as the prostitution that many of them are subject to obtaining the drug.

Dependent users are also referred for consultation with the psychiatrist for drug treatment for relief of signs and symptoms such as insomnia, anxiety, irritability, depression, psychosis caused by substance abuse. These appointments are scheduled once a month or every two months as requested by the doctor. In more advanced cases, the user is more physiologically compromised, such as alcoholic dementia or other disorders resulting from abuse / dependence. Users are referred only for drug treatment, as they do not benefit from support groups and therapeutic workshops. Particularly, P4 refers to referral dependent users for clinical assessments of liver function, neurological, among others, since these changes are often when chemical dependence has been in place for many years.

Relatives are referred to a specific support group. In this group, the professional carries out a guiding work about the context that involves the user of drugs, the care and support they need and the understanding of chemical dependence as a disease. In addition, it seeks a rapprochement of families with the user or dependent.

Our cross-drug, multi-drug groups have a goal, and we know more or less what kind of patient they have in it. I will not put a regular marijuana user along with a crack dependent. (P1)

[...] dependents will often require an approach that leads to other medical evaluations from the general clinical point of view. (P4)

\section{DISCUSSION}

The results of this study show that most participants recognize chemical dependence as a chronic disorder that develops over time through different phases. They also show that the criteria used to identify the consumption phase of alcohol and drug users are not different from those in the DSM-5 Diagnostic and Statistical Manual of Mental Disorders. These include periodicity of use, dose used, characteristics of the person making use of the substance or context, including tolerance, rate of absorption, chronicity of use, context in which the drug is consumed ${ }^{(6)}$. Nonetheless, it is necessary to consider that the criteria of the DSM-5 are focused primarily to identify situations already defined as disorders. In other words, the emphasis is still on situations where dependence is at an advanced phase, which points to the need for more investment to identify and act on the occasional and usual user steps.

Although the participants in this study did not mention the use of specific tools to identify the phase the user / dependent is in, the data show that they use consolidated criteria. In this sense, it can be said that they are criteria recognized in the literature on the subject.

Regarding periodicity, a recent study identified it through the frequency of use of crack in users of a CAPS AD, considering the use as daily, weekly or monthly. Most users often used the drug more than four times a week ${ }^{(7)}$. Another study on the pattern of drug use showed that the use of alcohol among crack users 
occurred predominantly in youth, with a dependence characteristic for a period of more than ten years ${ }^{(8)}$. This frequency was also measured by the participants of the present study in other drugs, such as alcohol, in which professionals report that when the user arrives at the treatment service, dependence has already been established for years.

The exclusive use of marijuana is perceived by study participants as a drug that does not cause social, family, financial and work repercussions. However, according to the DSM-5 dependence criteria, about $9 \%$ of those who experience marijuana will become addicted and may develop symptoms such as irritability, difficulty sleeping, dysphoria, and anxiety. In addition, early and regular use of marijuana provides an increased risk of marijuana dependence which, in turn, is a predictor of a greater risk of use of other illicit drugs ${ }^{(6)}$.

Cocaine powder is used occasionally at parties and usually associated with alcohol, in order to potentiate its effects ${ }^{(9)}$. In this study, cocaine was related to occasional users, including, for example, workers referred to CAPS AD by companies, but who have control over the drug.

Alcohol is estimated by the amount ingested, being expressed by small, moderate or high doses and the type of alcoholic beverage, which can be distilled or fermented. These criteria used to establish dependence are also evidenced in a study on the pattern of alcohol use, showing that more than half of the interviewees consumed high doses of alcoholic beverages every weekend, with a higher preference for beer followed by wine ${ }^{(10)}$. In addition, occasional use of drugs such as alcohol, tobacco, and marijuana may be associated with dependence on drugs considered to be "heavier" as they are consumed in the search for better effects and reduction of unwanted effects ${ }^{(11)}$.

The study participants establish dependence according to the type of drug used, especially crack, which accelerates the development process with little time of use. However, other studies indicate that there are usual users of crack, who use for up to five years, although the great majority of the studied population makes dependent use for a period of six to ninety years. The age of the users has been investigated due to the longevity of consumption, which could indicate an adaptation of them to the culture of the drug. The strategies developed by users to deal with the risks of drug use indicate that changes in crack culture may contribute to an increase in life expectancy, since the occurrence of users with more than five years of use has increased exponentially ${ }^{(7-8,12-13)}$. In this sense, studies investigated some strategies developed by crack users and found that they employed simple strategies, such as drug use in protected places, compliance with commitments, including drug traffickers, not to attract neighborhood and police attention and to combine crack use with other drugs such as marijuana or alcohol (14-15).

In the process of development of chemical dependence, the repercussions caused by the misuse of alcohol and other drugs are perceived by the participants of this study, which corroborates with another study that shows that dependence damages the family nucleus, coexistence, bonding and confidence, causing suffering and fragility in relationships. Thus, the experience lived by the family can be devastating in the physical, financial and in the interpersonal and social relations, considering also the social vulnerability that, often, the dependent is ${ }^{(16)}$. It was also mentioned that the person only seeks help when the dependence is already installed, as shown in another study in which the dependents at this phase are repentant. With this, they are more motivated to seek help, because they are at "rock bottom", term used by the users themselves ${ }^{(17)}$.

On the other hand, the results of this study show that the actions carried out by the study participants are primarily aimed at guiding and referring people using alcohol and other drugs from the PTS to support groups, therapeutic workshops and individual visits. Although few occasional users attend CAPS AD, as addressed by participants, preventive work is undertaken when requested by schools. This work corroborates with another study that showed that the actions directed to this population need to be focused mainly on the prevention of drug use in adolescence, with differentiated and earlier approaches, giving support to users before the setting of dependence, avoiding losses and repercussions in the adulthood ${ }^{(18)}$.

The professional, when serving these adolescents, needs to know their social relations, places of coexistence, family, motives that led to the beginning of drug use and situations of violence experienced $^{(19)}$. Moreover, because of the caffeine present in the alcoholic beverage, use at this phase may potentiate usual consumption, as well as the progression to more potent or dangerous drugs, and intervention is very important to avoid the use $\mathrm{e}^{(20)}$.

Women are assisted in the study CAPS AD, users of alcohol and other drugs that are often referred by the local Guardianship Councils because their children's custody is being threatened or have already been withdrawn. In this particular CAPS AD, the particularities of these women who suffer many losses due to substance abuse are addressed. Studies show that the dependence of crack among women causes great repercussions, since they are usually single, mothers of childbearing age and without own income, susceptible to situations of violence and prostitution in exchange for the drug ${ }^{(7,18)}$.

The referral of family members to the support group is also important for the treatment of the dependent, as it favors in the restructuring of the lifestyle and changes in the behavior of the drug user. The family's difficulty in dealing with chemical dependence can be diminished by specific therapeutic accompaniments that offer emotional support and promote the development of skills in handling and coping with risk situations to relapse of the dependent user. In addition, participation in the group helps families understand chemical dependence as a chronic disease ${ }^{(19-21)}$.

\section{Study limitations}

Due to the limitations of the study and the size of the sample, studies are suggested that consider other contexts of action of the multidisciplinary team, such as interviews with drug users and relatives, in order to know the perspective of those who are assisted in mental health services. It is believed that the research can be carried out in other services of the network of attention, in order to evaluate if the forms of diagnosis, actions and referrals carried out consider the different phases of the process of sickness of the disorders of the abuse and dependence of alcohol and drugs, ensuring a convergent care with the service user's need. 


\section{Contributions to the fields of Nursing, Health or Public Policy}

The results of this study showed that despite the frequent distancing between professional training and practice in the field of Mental Health, nurses are able to perform their integrated work in the multidisciplinary team. The study also contributes to show the need for professionals and nurses to particularly appropriate knowledge about the chronic and progressive nature of the process of becoming dependent chemist to effectively plan their actions competently.

\section{FINAL CONSIDERATIONS}

By identifying, based on the perception of the professionals about chemical dependence, the interventions they consider pertinent to the different process phases of becoming chemical dependent, they found that although the professionals showed knowledge about the disease chronicity, their interventions at CAPS AD mainly contemplate the dependent user, corresponding to the study's third phase.
Considering the characteristics of chemical dependence as a chronic disease that affects a significant contingent of the world population, the study showed that work with dependence is a challenge for CAPS AD multidisciplinary team professionals, since it requires knowledge and preparation, this being through capacities and specializations in the area. The study also pointed out the need to know what care strategies are recommended for these people, adjusting their actions according to the specific phases, not limited to referrals and guidelines in the services, as indicated by the results.

In this sense, results highlight the importance of qualification in the training of professionals and the development of phase training programs for alcohol and other drug users. In addition, the development and implementation of public policies aimed at identifying and intervening in cases of early-phase drug use consist of effective actions to prevent chemical dependence.

\section{FUNDING}

Research performed with support of the Comissão de Aperfeiçoamento de Pessoal de Nível Superior (CAPES) - Finance Code 001.

\section{REFERENCES}

1. Ministério da Justiça (BR). Secretaria Nacional de Políticas sobre Drogas (SENAD). A prevenção do uso de drogas e a terapia comunitária. Brasília: SENAD; 2006.

2. Freitas ER, Joaquim RM, Tabaquim MLM, Camargo AP. Avaliação neuropsicológica das funções executivas de mulheres em estado de dependência química. Arch Health Invest. 2016;5(1):14-24. doi: http://dx.doi.org/10.21270/archi.v5i1.1296

3. Ministério da Saúde (BR). Secretaria de Atenção à Saúde. A Política do Ministério da Saúde para atenção integral a usuários de álcool e outras drogas [Internet]. Brasília; 2004 [cited 2017 jul. 16]. Available from: http://bvsms.saude.gov.br/bvs/publicacoes/politica_atencao_ alcool_drogas.pdf

4. Ministério da Justiça (BR). Secretaria Nacional de Políticas sobre Drogas (SENAD). Efeitos de substâncias psicoativas: módulo 2. 7a ed. Brasília: SENAD; 2014. Available from: https://www.supera.org.br/wp-content/uploads/2016/03/SUP7_Mod2.pdf

5. Minayo MCS. O desafio do conhecimento: pesquisa qualitativa em saúde. 11 a ed. São Paulo: Hucitec; 2010.

6. American Psychiatric Association. Manual diagnóstico e estatístico de transtornos mentais: DSM-5. 5a ed. Porto Alegre: Artmed; 2014.

7. Almeida CS, Luis MAV. Sociodemographic characteristics and pattern of use of crack and other drugs in a CAPS AD. Rev Enferm UFPE. 2017;11(Suppl. 4):1716-23. doi: 10.5205/reuol.10438-93070-1-RV.1104sup201714

8. Seleghim MR, Oliveira MLF. Padrão do uso de drogas de abuso em usuários de crack em tratamento em uma comunidade terapêutica. Rev Neurocienc. 2013;21(3):339-48. doi: 10.4181/RNC.2013.21.800.10p

9. Tarter RE, Kirisci L, Reynolds M, Horner M, Zhai Z, Gathuru I, et al. Longitudinal modeling of the association between transmissible risk, affect during drug use and development of substance use disorder. J Addict Med. 2015;9(6):464-9. doi: 10.1097/ADM.0000000000000163

10. Anjos KF, Santos VC, Almeida OS. Caracterização do consumo de álcool entre estudantes do ensino médio. Rev Baiana Saúde Pública. 2012;36(2):418-31. doi: 10.22278/2318-2660.2012.v36.N2

11. Olthuis JV, Darredeau C, Barrett SP. Substance use initiation: the role of simultaneous polysubstance use. Drug Alcohol Rev. 2013;32(1):6771. doi: http://dx.doi.org/10.1111/j.1465-3362.2012.00470.x.

12. Carvalho MRS, Silva JRS, Gomes NP, Andrade MS, Oliveira JF, Souza MRR. Motivations and repercussions regarding crack consumption: the collective discourse of users of a Psychosocial Care Center. Esc Anna Nery. 2017;21(3):e20160178. doi: 10.1590/2177-9465-ean-2016-0178

13. Teixeira AA, Kantorski LP, Corrêa ACL, Ferreira RZ, Ferreira GB, Espírito Santo MO. Crack users - developing strategies to face the risks of the consumption. Rev Pesqui:Cuid Fundam. 2015;7(2):2393-404. doi: 10.9789/2175-5361.2015.v7i2.2393-2404

14. Ribeiro LA, Sanchez ZM, Nappo SA. Surviving crack: a qualitative study of the strategies and tactics developed by Brazilian users to deal with the risks associated with the drug. BMC Public Health. 2010;10(1):671. doi: 10.1186/1471-2458-10-671

15. Valdez A, Kaplan C, Nowotny KM, Natera-Rey G, Cepeda A. Emerging patterns of crack use in Mexico City. Int J Drug Policy. 2015;26(8):73945. doi: 10.1016/j.drugpo.2015.04.010

16. Czarnobay J, Ferreira ACZ, Capistrano FC, Borba LO, Kalinke LP, Maftum MA. Intrapersonal and interpersonal determinants perceived by the 
family as a cause of relapse in drug users. REME - Rev Min Enferm. 2015;19(2):100-6. doi: 10.5935/1415-2762.20150028

17. Pedrosa SM, Reis ML, Gontijo DT, Teles SA, Medeiros M. The path to crack addiction: perceptions of people under treatment. Rev Bras Enferm. 2016;69(5):899-906. doi: 10.1590/0034-7167-2016-0045

18. Capistrano FC, Ferreira ACZ, Silva TL, Kalinke LP, Maftum MA. Perfil sociodemográfico e clínico de dependentes químicos em tratamento: análise de prontuários. Esc Anna Nery. 2013;17(2):234-41. doi: 10.1590/S1414-81452013000200005

19. Moura NA, Monteiro ARM, Freitas RJM. Adolescents using (il)licit drugs and acts of violence. Rev Enferm UFPE. 2016;10(5):1685-93. doi: 10.5205/reuol.9003-78704-1-SM.1005201614

20. Kirisci L, Tarter R, Ridenour T, Reynolds M, Horner M, Vanyukov M. Externalizing behavior and emotion dysregulation are indicators of transmissible risk for substance use disorder. Addict Behav. 2015;0:57-62. doi: 10.1016/j.addbeh.2014.10.028

21. Horta ALM, Daspett C, Egito JHT, Macedo RMS. Experience and coping strategies in relatives of addicts. Rev Bras Enferm [Internet]. 2016;69(6):962-8. doi: 10.1590/0034-7167-2015-0044 